\title{
Trajetórias Espaciais de Jovens do Sexo Masculino e os Agenciamentos da Morte na Cidade de Ponta Grossa - PR
}

\author{
Spatial Trajectories of Young Men and Assemblages of Death in City of Ponta \\ Grossa - PR
}

\author{
Fernando Bertani Gomes \\ Universidade Estadual de Ponta Grossa - Brasil \\ ferbg28@gmail.com
}

\section{Resumo}

$\mathrm{O}$ artigo tem como objetivo compreender a relação entre as trajetórias espaciais de jovens do sexo masculino e a morte por homicídio na cidade de Ponta Grossa, Paraná. O perfil mais vitimado por homicídio na cidade são pessoas do sexo masculino com idade entre 15 e 25 anos, moradores de áreas periféricas pobres do espaço urbano, com baixa escolaridade e envolvidos com drogas. Tomado esse perfil, o referencial empírico da investigação foi estabelecido através de jovens em tratamento das drogas na Comunidade Terapêutica Marcos Fernandes Pinheiro. Foram realizadas 6 entrevistas semi-estruturadas, através das quais foi possível categorizar as trajetórias espaciais em que a violência e a morte estão presentes como um elemento inter-relacional. Espacialidades como a rua, a vila e o tráfico de drogas foram estabelecidas como resultado de múltiplas interrelações efetivadas pelas trajetórias espaciais performadas por formas de subjetividade violentas. A morte violenta apresenta uma polivocalidade mediante a rede de amizades da vila, as performances de masculinidade violenta e os dispositivos econômicos informais da territorialidade do tráfico de drogas. Também foram organizadas quatro faces da morte no cotidiano dos sujeitos investigados: a morte como uma experiência limite, como risco constante, a morte do outro e por fim as autorias de assassinatos.

Palavra-Chave: Espacialidade; Masculinidade; Morte; Juventude; Homicídio.

\begin{abstract}
This article aims understanding the relation between spatial trajectories of young men and death by homicide in city of Ponta Grossa, Paraná. The most victimized people are men in age of 15 and 25 years old, living in poor peripheral areas of urban space, with low schooling and involved with drugs. Taking this profile, the empiric referential of investigation was established through young in drug treatment in Therapeutic Community Marcos Fernandes Pinheiro. Six semi-structured interviews were done and spatial trajectories that death and violence are presents as an inter-relational element were categorized by the interviews. Spatialities as street, village and drug traffic were established as a result of multiple interrelations made by spatial trajectories performed by forms of violent subjectivities. Violent death shows a polyvocality in front of friendship network of village, the violent masculinity performances and the informal economic devices of territoriality of drug traffic. Also, four faces of death were organized in the daily of investigated individuals: death as a limit experience, death as a constant risk, death of the other and finally the authors of murder.
\end{abstract}

Keywords: Spatiality; Masculinity; Death; Youth; Homicide. 


\section{Introdução}

O artigo está posicionado na seguinte questão: Como a morte se constitui em elemento de vivência cotidiana dos jovens em situação de vulnerabilidade à morte?. A morte por homicídio no Brasil apresenta uma 'ordem espacial' (GOMES, 2012) se considerado o perfil das vítimas de assassinato. A morte violenta no país tem como ator e vítima a juventude (15-24 anos), e dentre esse grupo, 93,9\% das vítimas de morte por homicídio, são do sexo masculino (WAISELFISZ, 2011). Considerando a análise dos casos de homicídio da cidade de Ponta Grossa - PR, o crime apresenta com mais frequência vítimas jovens, entre 15-25 anos, envolvidos na espacialidade das drogas e moradores de áreas periféricas pobres da cidade (GOMES, 2013).

Nesse sentido, foi tomado como referencial empírico, adolescentes do sexo masculino em tratamento das drogas na Comunidade Terapêutica Marcos Fernandes Pinheiro da mesma cidade. A instituição de tratamento atende pessoas do sexo masculino menores de 18 anos. Dentre o total de meninos que passaram pela casa, $75 \%$ tinham entre 15 e 18 anos de idade e todos moradores de vilas periféricas da cidade de Ponta Grossa. Foram realizadas seis entrevistas semiestruturadas e analisadas conforme conteúdo de Bardin (1977).

$\mathrm{O}$ artigo preocupa-se em tomar a morte como uma experiência cotidiana, através de diferentes perceptos e afetos que compõem as subjetivações de uma espacialidade violenta

\section{Diagramas: micro-relações espaciais de poder}

A morte está presente no cotidiano dos jovens do sexo masculino, moradores de vilas periféricas pobres, envolvidos com as drogas (GOMES, 2013). Por meio dos estratos de saberes tramados na espacialidade desses sujeitos, a morte toma sua face, ou melhor, é enunciada e/ou toma visibilidade. Essas afirmações estão posicionadas sob as discussões sobre saber e poder da obra de Michel Foucault. Todavia, trarei à cena por meio de outro filósofo francês, Gilles Deleuze escreveu um livro intitulado Foucault, a obra é um 'ritornelo' do encontro entre os dois filósofos. Pode-se dizer que é uma Obra-comentário da filosofia de Foucault, mas vai, além disso, é a própria junção com a filosofia deleuziana. É o que Deleuze denomina como 'enrabada', ou 'imaculada conceição', o filósofo assim descreve: "eu me imaginava chegando pelas costas de um autor e lhe fazendo um filho, que seria seu, e, no entanto seria monstruoso" (DELEUZE, 1992, p. 15). Na obra Foucault, Deleuze, pode-se dizer, 'geografizou' a obra do filósofo Michel Foucault, principalmente com as noções de estratificações do saber e diagramas do poder.

Ao classificar Foucault como um novo 'cartógrafo', Deleuze (2008) descreveu sua potencialidade em construir 'mapas', ou melhor, 'diagramas', que designam um conjunto de linhas diversas funcionando ao mesmo tempo, essas linhas são os elementos constitutivos das coisas e dos acontecimentos. Dessa forma "cada coisa tem sua geografia, sua cartografia, seu diagrama" (DELEUZE, 1992, p. 47). Brincando com as palavras, o autor trata os diagramas, como máquinas abstratas "casi muda y ciega, aunque haga ver y haga hablar" (2008, p.61), a fim de lembrar a impossibilidade de esgotar as relações de forças presentes em um 'diagrama'. Ele é um mapa das relações de forças, porém as forças se atualizam ao mesmo tempo em que os quadros descritivos são construídos. Essa atualização ocorre na forma de enunciados ou visibilidades, ou seja, as relações de poder sempre se atualizam na forma de saber, responsável por dar forma e sentido às coisas, porém esse saber é constantemente atualizado pelas relações de 
forças que são múltiplas, difusas e instáveis.

É importante distinguir dois momentos na biografia de Michel Foucault, das arqueologias do saber e as genealogias do poder, nesse momento recorro à contribuição de Fonseca (2011):

A arqueologia procura, portanto, apreender a irrupção de uma singularidade não necessária. Ora, em Foucault podemos chamar de 'acontecimento' a irrupção de uma singularidade não necessária que, de algum modo, continua a nos atravessar. Nossa atualidade comportaria, assim, a marca desses acontecimentos - que são passados, mas que continuam presentes [...] A genealogia percorre o engendramento de uma determinada singularidade, acentuando as relações de poder que determinam a sua constituição, a fim de reparar de que modo estas singularidades modelaram o presente (FONSECA, 2011, p. 250).

O saber figura as matérias formadas (substâncias) e funções formalizadas, distribuídas em segmentos de ver e falar; luz e linguagem. São as estratificações agenciadas em nossa sociedade. Ainda que agenciamento possa ser usado como a relação entre as linhas de forças, com a potencialidade de afetar ou ser afetado, numa lógica mais local, é nesse sentido que há uma releitura, ou uma sobreleitura geográfica de Deleuze (2008) sobre a obra de Michel Foucault. As relações de forças por serem instáveis e difusas, não são localizáveis, porém são locais. O diagrama é uma multiplicidade espaço-temporal em devir, um conjunto de relações de forças arranjando os estratos - curvas e nós, do saber. Aqui toma uma relação de cumplicidade com as noções de espaço em Massey (2008).

Por meio das performances de masculinidades marginalizadas, temos um agenciamento com práticas agressivas, violentas e desafiadoras expressas nas formas de subjetividade presentes nas espacialidades vivenciadas pelos jovens do sexo masculino, moradores de vilas periféricas. Pelo desejo de ser frente ao outro, compõe performances espaciais, ou como propõe Rose (1999), 'fantasias', que os posicionam nas relações de poder.

Através de performances, tramadas pelo gênero, os meninos utilizam-se de violência, prova, desafio, confronto, etc. Mas é importante ressaltar que nas mesmas expressões que figuram violência, estão agenciados os 'camaradas', ou seja, as formas de amizade cotidianas. Isso pode ser exemplificado com a fantasia que os jovens têm quanto ao uso de drogas. $\mathrm{O}$ acesso à droga está interseccionado à idade, que geralmente acontece entre a infância e a juventude (11 anos). No qual fazem uso, certo de que serão vistos como 'vida louca' na vila onde moram. Os domínios do que seria um 'vida louca' está tramada pelo gênero, na medida em os jovens compõem performances de 'delinquentes', 'independentes' ou 'inconsequentes', sobretudo, exacerbam sua condição de marginalidade dos domínios institucionais e estruturas urbanas.

A 'vida louca' é enunciada e toma sua visibilidade fazendo-se bastante presente na 'rua', morando em 'vila' periféricas, fazendo 'uso de droga', na adolescência principalmente, fazendo os 'corres' praticando 'roubo', convivendo e interagindo em 'mocós', participando de 'cenas embaçadas' matando ou vendo matar. Enfim, são poderes estratégicos que batem e afetam os jovens e estes rebatem e afetam as relações de poder engendradas em sua vivência cotidiana. 


\section{Práticas espaciais de jovens do sexo masculino e os enunciados da morte}

As análises elaboradas especificamente sobre as evocações sobre a 'morte', foram estabelecidas a partir da sistematização de 402 categorias discursivas, retiradas das entrevistas realizadas. Foram organizadas e analisadas as espacialidades mais frequentes nas evocações e a partir dessas, que são 'rua', 'vila', 'casa', 'mocó' e 'tráfico', analisou-se as evocações presentes em cada uma delas, de maneira que as evocações categorizadas especificamente como 'morte' serão tomadas restritamente aqui.

Para analisar as evocações de 'morte', considerou-se todas as evocações sobre a morte e as espacialidades em que ela está presente, fica assim organizado: Rua (28\%); rua-instituição de tratamento $(22 \%)$; vila $(16 \%)$; mocó $(12 \%)$; tráfico $(10 \%)$; casa $(8 \%)$; instituição de tratamento $(2 \%)$ e centro $(2 \%)$.

A 'morte' marca presença de maneira mais frequente na 'rua', como a espacialidade mais evocada nas entrevistas. Seguido da 'ruainstituição de tratamento' são evocações fluídas entre as duas espacialidades que se destinam às atividades da 'rua', contudo é uma 'rua' ressignificada pela convivência na Comunidade Terapêutica, que tem sua estrutura de tratamento baseada em alguns conceitos ideais como religião cristã e a família. A rua passa a ser descrita por meio de uma fusão discursiva com as práticas de ensino e tratamento da entidade religiosa.

Serão analisadas as espacialidades centrais da 'rua', 'vila', 'mocó' e 'tráfico'. Isso não quer dizer que as outras espacialidades serão negligenciadas, somente que serão trazidas à discussão em momentos pertinentes da análise das vivências espaciais dos entrevistados.

Antes de passar para as espacialidades citadas é preciso esclarecer que as evocações de 'morte' foram categorizadas em quatro eixos discursivos:

- 'Experiência limite': são evocações sobre a saúde e o corpo do entrevistado na condição de vítima de agressões, violência, tentativas de homicídio, como também dos excessos no uso de determinada droga, enfim, designa experiências que os posicionaram no limite da vida, na experiência de quase morte, seja qual for a causa, desde uma estória da infância até tiros de arma de fogo.

- 'Morte de si': se diferencia da 'experiência limite', diferente de uma violência praticada trata da violência em potencialidade. A morte como possibilidade cotidiana. O 'si' está longe de ser do sujeitosubstância, como aquele sempre idêntico a si mesmo, mas trata da compreensão de um sino-mundo, uma plena imersão ao mundo compartilhado espacialmente. São as leituras dos outros e de si, a partir de suas ocupações e relações estabelecidas posicionando inclusive a morte e seu risco iminente. Essa categoria evocativa trata do medo, dos riscos, do futuro, das expectativas de vida e morte.

- 'Morte do outro': é a experiência do outro e da morte do outro, da figura do corpocadáver, do testemunho de assassinatos, das estórias veiculadas na vila onde mora, ou seja, toda morte expressa na experiência do entrevistado com outra pessoa, amigo, conhecido e desconhecido, familiar ou apenas um corpo.

- 'Morte como autor': são as experiências de autoria de homicídio, trata-se da atividade de matar alguém, contado e praticado pelo próprio entrevistado.

As espacialidades analisadas, a seguir, serão organizadas tomando essas quatro categorias evocativas sobre a 'morte' e levando em conta toda a construção conceitual construída sobre cada espacialidade. 
A 'rua' estabelece sua relação com a morte de maneira mais frequente na forma de 'experiência limite' (50\%), seguido de 'morte de si' $(21,4 \%)$, autorias de assassinatos 'morte como autor' $(14,3 \%)$ e 'morte do outro' $(14,3 \%)$. A 'rua' como lugar do movimento, do encontro com o desconhecido e dos agenciamentos ao acaso, onde as relações estão abertas constantemente à eventualidade, é uma espacialidade buscada pelos jovens do sexo masculino por essas características, onde estes compõem atos de 'des-territorialização', como linha de fuga de elementos fixos do cotidiano, como espaços disciplinares da escola, família, trabalho. Lembrando que ao tomarem esse movimento simultaneamente agenciam-se às condutas da 'rua'. A 'rua' se expressa por uma potencialidade na abertura das relações e na eventualidade de trajetórias, contudo, não deixa de ter seus poderes estratégicos e processos de subjetivação singulares.

As formas de subjetividade coexistem aos estratos do saber e ambos são atualizados pelas relações de força, difusas, por isso, não localizáveis, porém locais. Em outras palavras, são 'performances corporalizadas' (ROSE, 1999) tomando sentido entre os domínios do sujeito, e sujeito homem, mergulhado na 'fantasia' praticada no espaço performático da 'rua', que pelo desejo de ser frente ao outro, agencia-se às práticas que dão sentido e posicionam um corpo jovem, do sexo masculino, na espacialidade da 'rua'.

A 'morte' viva no cotidiano dos entrevistados tem suas singularidades e estão inter-relacionas ou interseccionadas em outros elementos da 'rua', portanto, se faz pertinente distinguir quais são as categorias evocativas presentes na rua e qual posição 'diagramática' na referida espacialidade. Como já comentado a 'experiência limite' apresenta-se como a mais frequente face da morte na 'rua' e podese dizer que as experiências de aproximação da morte, ou melhor, de quase morte, tomam três características. A primeira são as experiências interseccionadas com o 'uso de droga', referente aos excessos no uso interferindo a saúde do corpo, como exemplifica a fala a seguir:

Eu usei oxi tá ligado, daí eu nossa, cheguei à beira da morte, estava quase morto, os cara só falava: oh melhor a senhora mandar preparar já o caixão que teu filho tá morrendo, chegou a ponto em que eu só respirava só pelo nariz assim, por causa que não tinha respiração, fiquei inchado, meus braço inchou tudo essas parte aqui assim, eu não podia me retorcer que dava pra sentir o inchaço dos lado e uma pedra que eu fumei da oxi, daí nossa sofri demais cara (Severino Espiado) ${ }^{1}$.

A segunda característica é a expressão das trajetórias casuais, sem muitos planos e estabelecendo vínculos temporários e circunstanciais. Por meio de práticas de lazer e festividade, na presença de amigos e desconhecidos, fazendo uso de bebidas alcoólicas e diferentes drogas. Suas condutas vão se estabelecendo conforme as situações, quase sempre desordenadas, que trazem aos meninos experiências de confusão, briga e desmaio, como demonstra a fala a seguir:

[Você já teve medo de morrer?] Ah já né. [Alguma situação que você quase morreu?] Ah me desmaiaram assim, dai me deixaram num lugar assim e quando eu acordei estava sozinho. [Porque que te desmaiaram?] Não sei, os cara vieram assim e me desmaiaram, não sei se foi na pancada, eu estava bêbado, daí acordei assim no meio do mato assim, eu saí do meio do mato, fiquei a madrugada inteira andando e quando saí na rua assim, fui chegar lá em casa era $6 h$ da manhã assim, estava clareando o dia. Daí, quebraram meu braço, só que eu não sei quem que foi, nem vi o que aconteceu, só na hora que 
eu acordei, cheguei em casa, não tinha visto nada, daí eu dormi e na hora que eu acordei meu braço estava quebrado, estava inchado (Polaco Bala).

Por fim são as experiências limites referentes a agressões, tentativas de homicídio e ameaças de morte. As ameaças ocorrem na intersecção das práticas do tráfico de drogas, caracterizadas como uma cobrança de dívida, e estão trabalhadas na espacialidade do 'tráfico' sob a experiência de 'morte de si'. Em conformidade com a espacialidade da 'rua' as ameaças ocorrem sem um sentido ou finalidade coerente, como demonstra a fala de Ribeiro Loco:

Esses tempos que eu fugi eu estava usando e tal, dai eu falei: o cara, tinha um outro amigo meu e eu falei: o cara, vamos lá. Ele estava de moto, vamos lá no... vender um bagulho, vender uma blusa pra nós fumar. A blusa era minha e tal. Na hora que eu cheguei lá o cara puxou um 32 pra mim assim, tá ligado, puxou um 32 assim e falou: ó cara, vaze daqui cara se não eu te mato Ah eu não vi nada né, sumi da reta assim, mas foi bem desesperador e tal, foi sério mesmo, o cara puxou assim, mas graças a Deus o cara puxou só pra me assustar entendeu, porque acho que dois dias depois eu fiquei sabendo que não tinha bala entendeu, mas o cara puxou assim e se o cara fosse pra me matar não tinha como fugir entendeu, porque o cara puxou assim e falou: ó cara, vaze daqui. Era só pra assustar mesmo, mas eu não sabia disso né e saí se perdendo tudo. Um outro cara que estava lá que me conhecia, porque eu vi o cara lá né, ele me contou que não tinha e tal, nossa daí eu fiquei pensativo né, falei nossa: me escapei da morte; Foi bem sinistro e tal (Ribeiro Loco).

As tentativas de homicídio figuram na forma de vingança de desavenças estabelecidas no cotidiano da 'rua' e/ou interseccionadas à espacialidade da droga, como demonstram as falas a seguir:

[E teve outras vezes de correr risco assim?] Ah, teve, teve né cara, pra falar a verdade, teve altos né cara, uma vez tentei matar um cara lá, daí chegou o cara lá com um revólver atrás de mim lá, daí eu saí correndo, um cara grandão assim (Jason Rim).

Eu dei mio pro meu cunhado, eu roubei o notebook do meu cunhado, eu roubei o notebook do meu cunhado daí a minha irmã falou lá pra ele sabe, que eu tinha fumado com ele. Daí eu não tinha fumado com o cara, daí eu estava sentado no carreiro espiando, o cara chega com uma pedra assim e falou: o que que a tua irmã foi loquear lá comigo lá, falou que você tinha fumado um notebook comigo. Aí eu falei: não, não tem nada haver e fiquei quieto assim, estava na pira da pedra né, do crack. Daí o cara passou assim e de repente pegou um cano do bolso, deu dois tiro no mato, pegou assim, no meio do matão. Oh cara! sê o cara quisesse me matar assim... porque eu estava virado contra ele, só que daí ele passou assim e conversou comigo um pouco daí foi e voltou (Jason Rim).

Por vezes, as experiências de quase morte tornam-se mais intensas, como em casos em que chegam a levar tiro de arma de fogo, como conta Jason Rim:

Eu peguei e fumei minhas roupas, daí no dia que eu fumei minhas roupas lá, levei um tiro do cara, estava no meio do mato, estava no meio do mato, daí quando saí do meio do mato e pá, acendi um cigarro com um cara lá, o cara com a muié dele estavam vindo assim, daí o cara já me cruzou já, daí já comecei a correr na hora, a hora que eu comecei a correr ele já saiu assim e me

\section{Fernando Bertani Gomes}


deu um tiro nas costas, acertou um. [Acertou um nas costas?] É, aqui. [Não deu nada?] Hã? [Saiu dessa fácil ou ficou um tempo no hospital?] Ah, fiquei uma semana no hospital só (Jason Rim).

A 'rua' também é lugar da 'morte como autor'. As evocações sobre autoria de homicídio são as menos frequentes e estão distribuídas na 'rua', no 'mocó' e no 'tráfico', sendo que na 'rua' concentra-se a maior frequência. Através das 'cenas loucas' presentes na 'rua', interseccionadas ao 'uso de droga' e expressões de 'masculinidade' desafiadora e agressiva, as formas de subjetividade aproximam-se da prática do assassinato, como demonstram as falas a seguir:

Eu falo, eu não tenho vergonha, eu virei bandido, pra mim era matá e matá e querer dinheiro e muié né cara (Severino Espiado).

Uma vez assim o cara tentou umas ideia errada, falei: oh cara o negócio é o seguinte cara, na hora que o cara menos esperou já entortei três sapêco nas costas dele tá ligado, daí eu fui preso, fiquei um tempo preso, daí saí já fiz o '157’2 (Severino Espiado).

As formas de subjetividades em questão estão agenciadas à espacialidade da droga e a performances de masculinidades presentes na 'rua' e, por sua vez, esses elementos lhes trazem vínculos de sociabilidade, através dos 'camaradas', como também os posicionam na centralidade das relações de poder, na medida em que tomam parte de práticas como usar droga, desafiar, provar seu discurso e matar. Sob as trajetórias expressas na 'rua' está bem presente a performance de coragem e encorajamento, como conta Ribeiro Loco:

[Você teve medo de morrer alguma vez?] Ah eu não via nada né, pra mim tanto faz; Os cara falava: vamo em tal lugar, ah vamo aí, vamo aí não vai dar nada; Se der da pouco, igual os cara falavam né, se der da pouco (Ribeiro Loco).

Portanto, a 'rua' dá lugar às experiências de quase morte, através das 'cenas loucas' e das práticas de assassinato, interseccionadas à espacialidade da droga e performances de masculinidade.

A segunda espacialidade a ser analisada é a 'vila' que atende a 16\% das evocações sobre morte. Essa espacialidade expressa as seguintes categorias evocativas da morte: 'morte do outro' (62,5\%); 'morte de si' (25\%) e 'experiência limite' (12,5\%). Portanto, a 'vila' dá lugar às experiências de morte através do outro que morre. Estão atravessadas nela as estórias contadas de morador a morador, entre os familiares, que partilham do mesmo local de moradia.

Falar sobre uma espacialidade da 'vila', designa, nessa pesquisa, um diagrama de múltiplas trajetórias em movimento e interrelacionadas ente si, compostas por poderes estratégicos, estratos do saber e formas de subjetividade, todos constantemente atualizados pelas relações de força. Acessando isso pelas categorias discursivas, estabelecidas das entrevistas, que enunciam, materializam e dão visibilidade ao diagrama.

Entretanto, não se deixa de agenciá-lo ao seu topos, ou seja, a 'vila' traz esse nome como um esforço linguístico no sentido de que organizando um diagrama ele não venha a flutuar nos domínios da linguagem e do discurso. É certo que essa espacialidade da 'vila' está diretamente relacionada à vila, local de moradia a qual as evocações situam. Contudo, a relação se faz pela via dos acontecimentos, não da materialidade ${ }^{3}$. A 'vila', dessa forma, é também o local de moradia e seus limites circundantes, mas não só.

Em conformidade com o perfil de vítimas 
de homicídios na cidade de Ponta Grossa-PR apresentado por Gomes (2013), onde a maioria das vítimas são moradores de vilas periféricas, os entrevistados que partilham dessas localidades convivem com essa realidade. Assim, não poderia deixar de estar presente nas inter-relações de 'vila' a morte do outro.

Essa trama relacional dá lugar às experiências de morte do outro que toma diferentes facetas, como por estórias interseccionadas com a 'família':

[Lá na tua rua morreu alguém já?] Já, uma vez um outro lá tentou roubar lá o cara, daí meu padrinho, esse que matou o cara é irmão do meu padrinho, tá ligado. Meu padrinho morreu do mesmo jeito que o irmão dele matou o cara, entendeu? Igual os cara falam lá, tá pagando né. Daí o cara pá, não sei o que aconteceu, ele tentou roubar, diz que duas de 10 do cara lá, na hora que o cara desceu do carro. Daí nessa estava eu e o meu tio indo mostrar a casa da minha mãe pra uma pessoa que nós ia vender. Chegamos lá tinha um cara esticado, o cara esticado mesmo. Na frente da casa do meu irmão, que é hoje né, que é do lado assim, tipo tem um poste assim e o cara esticado lá, bem cabulozo né cara; Foi bem trágico né (Ribeiro Loco).

A 'vila' expressa a organização de grupos identitários agenciados por práticas de roubo e furto, pelo tráfico e uso de drogas, pelas festas e 'cenas loucas' de agressão, ameaça e morte. Essa rede de amizade estabelece seus pares e os outsiders, na figura do 'jaguára' que não partilha da mesma rede, ou da mesma 'vila', como demonstra Palhaço Zóio:

Conheço alguém que morreu esses dias mesmo, um camarada meu que os piá mataram lá, um tiro na cara e não sei quantos nas costas. [Por quê??] Não sei cara, as treta deles, daí os cara do
Mezomo, daí ele pego e ele conheceu um tal de Vadinho lá e esse Vadinho é um jaguára, daí esse Vadinho começou a bater, um cara forte também, o Gardinal, os cara forte, daí esse Vadinho apareceu lá na vila lá, daí o Rique falou que esse cara é um jaguára, falou pros cara: esse cara é jaguára, ligou pros cara, daí os cara: qual que é a da cena? Daí ele começou a explicar qual que é a da cena. Pra mim quem anda com jaguára, jaguára é né, daí o Rique ficava de boa né cara, foi lá pra casa da mãe dele no Mezomo. Daí um dia ele apareceu de moto lá pra matar ele, só que ele não falou nada ficou na dele assim, o cara chamando ele de jaguára ele ficou na dele, foi no dia o cara foi e matou ele, o cara nem esperava mas pegou e matou né (Palhaço Zóio).

Enquanto fazem uso de droga os meninos testemunham brigas. As brigas evocadas são sempre caracterizadas pelo confronto entre os jovens do sexo masculino que fazem uso de armas como faca, que na verdade são utilizadas imediatamente após qualquer tipo de discussão, xingamento ou agressão. A espacialidade da 'vila' é simultaneamente espaço de amizade e de 'cabreragem', ou seja, estado de alerta, afinal os confrontos acontecem de maneira circunstancial e exigem dos meninos agressividade, afinal por vezes está em jogo a própria vida. Ribeiro Loco exemplifica com seu testemunho:

Eu já vi assim, os cara matar outro na frente assim. Eu assim um pouco longe assim, fumando um pitile com o cara, o Catarina, um gordão. Daqui a pouco: ó, ó os cara; Daí os cara começaram a se enroscar assim, xingar o outro, daqui a pouco um já puxou uma faca e já furou o outro. Nós estava meio longinho assim tá ligado, eu falei: ó, ó, ó lá, eu vi que os dois já começaram a brigar né; Daí 
o cara deu uma facada assim, já saiu de pinote; O cara caiu, já era. Dois dias depois lá, acho que na Santa casa que o cara ficou, morreu (Ribeiro Loco).

Em seguida Ribeiro Loco posiciona sua performance de masculinidade agenciada a prática assistida:

\begin{abstract}
Ele não tinha morrido ainda ele estava meio mexendo assim; [Você tinha quantos anos?] Foi agora, acho que ano passado, no começo... Não, foi ano retrasado acho que final do ano assim. Daí nossa foi cabulozo mesmo, o cara assim morrendo e tal. Só que nossa eu era muito louco, falava: ah, marcou né, ficar devendo, isso que dá né cara. [É comum isso?] Pior que altas cena já dos cara se matarem lá, facada. Uma vez o cara do bar deu uns tiros nos cara, matou dois lá, já rolou alguma morte lá (Ribeiro Loco).
\end{abstract}

Ao afirmar-se como louco, Ribeiro Loco projeta sua forma-de-vida nas práticas das 'cenas loucas' e posiciona sua performance de masculinidade em cumplicidade às formas de subjetividade presente na 'vila', figurando um ser valente e que naturaliza as práticas circundantes a qual está mergulhado, por mais violentas que sejam. Quem morre na espacialidade da 'vila', morre porque 'marcou', ou seja, baixou a guarda, deixou de administrar sua performance de sujeito agressivo e bom administrador das práticas econômicas do 'tráfico de droga' também presente na 'vila'.

Os 'parceiros' da 'vila' que participam da espacialidade violenta do tráfico de drogas são lembrados pelas suas mortes violentas, como demonstra a fala a seguir:

Tinha um piazinho lá só que ele morreu em Curitiba, o apelido dele era Tito. Daí ele era usuário e tal, desandou. Ele já tinha vindo de Curitiba, só que a gente se conheceu bem. Ele morou um tempo lá e tal, daí em Curitiba os cara mataram ele tal, mataram ele feio mesmo, esquartejaram o cara lá. Foi bem cabulozo (Ribeiro Loco).

A morte na 'vila' se estabelece de maneira paradoxal. A 'morte do outro' se compõe em 'profundidade espacial', ou seja, está engendrada em múltiplos elementos, como nas formas de subjetividade, nas performances de masculinidade, nas redes de amizade e na espacialidade violenta da droga presentes na 'vila'. Contudo, essa morte bem viva, como potencialidade e presença espacial, por vezes não é tomada pelos jovens do sexo masculino como um elemento 'marcante', pelo contrário, é naturalizada e posicionada como periférica em relação ao 'uso de droga' e às performances de masculinidade, como demonstra a fala a seguir:

[E das pessoas que fumavam junto com você, era normal o: "vou morrer se eu não pagar"?] Ah os cara não estavam nem aí, porque lá tipo, igual eu, eu era meio dividido, eu curtia com os cara e curtia com os cara que vendia entendeu. Eu era bem dividido e tal. Os cara conversam, mas não se enturmam, tem os cara que vende e os cara que fumam entendeu, os cara se conversam igual, são camarada mas não se enturmam, não tem conversa. Só que daí os cara que pá, que fumavam estavam nem aí, tipo: vai ficar devendo pros cara? Ah tô nem aí cara, os cara: que venham cobrar. Os cara não tavam nem aí entendeu, morte assim, os cara não tavam nem vendo cara, quando você tá na droga você tá cego né cara. Mas acho que é isso, é o bagulho é louco cara (Ribeiro Loco).

A 'vila' é marcada pela 'morte do outro' figurada em estórias e testemunhos. Essas mortes são agenciadas em performances de 
masculinidade e em confrontos entre grupos identitários distintos. Sobre a 'vila' está interseccionada a espacialidade violenta da droga.

O 'mocó' está organizado nessa pesquisa como a conexão entre casa-amizade-tráfico e ainda que em menor frequência que a 'rua', apresenta como uma das categorias evocativas a 'morte como autor' (16,66\%), seguido de 'morte de si' $(16,66 \%)$ e em maior frequência apresenta experiências de 'morte do outro' $(66,66 \%)$ semelhante a 'vila'.

A espacialidade do 'mocó' é marcada na sua relação com a 'morte' por evocações detalhadas descrevendo toda a trajetória do assassinato de outrem, o que compõe uma posição de proximidade ou cumplicidade dos entrevistados nos homicídios. Mesmo considerando que a figura do 'camarada' surja no 'mocó', ou melhor, a rede de amizade dos jovens do sexo masculino estabeleça uma intersecção assim como na 'vila', na 'rua' ou no 'tráfico', ainda sim, o 'mocó' é tramado pelo tráfico e uso de droga e sobre eles estão engendrados as 'espacialidades espiadas', ou seja, aquelas trajetórias-condição do efeito do crack que compõe práticas violentas de brigas, desentendimentos e mortes, como mostra a fala a seguir:

[Você já viu alguém morrer perto de você?] Ah já, [...], nós tava fumando pedra, tava fumando pedra assim de repente um cara num quis, um cara não quis rachar com um outro cara que tava fumando comigo lá, o cara pegou uns ferrão e deu na cabeça do cara, daí matou o cara e jogou no esgoto, no meio do matão lá, ninguém sabe, até hoje (Jason Rim).

Além das relações de desentendimento, é preciso lembrar o caráter imanente das relações de poder, tomadas por Foucault (1988), “o poder está em toda parte; não porque englobe tudo e sim porque provém de todos os lugares" (1988, p. 103). As relações de poder não se constituem somente nas relações legais, mas no nível das disciplinas locais e suas práticas estratégicas de controle. Dessa forma, na teia de relações do 'mocó' interseccionado à 'moradia' se tem microrelações de poder atualizando os estratos de saber já organizados e agenciados. As formas de subjetividade estão agenciadas a performances de masculinidade e seus enunciados discursivos, em outras palavras, os meninos objetivando o governo local utilizam de formas de dizer-a-verdade pela via da prova e da ameaça, como mostra a trajetória contada por Palhaço Zóio, sobre um inquérito local:

[...] nós tinha um trinta e oito, daí sumiu o trinta e oito, ta ligado, só que era um cara que tava morando com nós, só que nós ficamos sabendo esses dias na rua, os cara foram atrás do cara, acharam o cara meio caído no mocó lá, o Paulinho, daí os maluco já pá, só que daí o cara diz que tinha o corpo fechado, tá ligado, esses bagúio de sarava. Os cara aceleraram ele, amarraram assim e os cara acelerando ele: que maluco, foi você que roubou o revolver, não sei que, [...] daí o Robert pegou uma espingarda que tinha no forro que um nóinha tinha vendido espingarda por pedra lá, engatilhou a espingarda no peito assim dele bem do lado do coração assim dele, negou o revolver assim ta ligado, fez 'tchec', nem estourou nada, daí o maluco: ih, com esses revolver véio vocês não vão me matar, porque diz que ele tinha o corpo fechado essas coisa, o Robert tirou a bala de um cano da espingarda pôs em outro engatilhou pôs na cara, arrancou um pedaço da cara, daí o cara ficou pá assim, só fui tirei o chinelo dele e saí vazado, taquêmo fogo na casa e saímo vazado (Palhaço Zóio). 
As mortes dos outros estão tramadas nas 'cenas loucas' que compõem uma trajetória fluída entre a 'rua', o 'tráfico' e o 'mocó', que por vezes encontra como topos, o 'barraco'. Essas trajetórias posicionam a morte como elemento naturalizado, que mesmo se fazendo presente, não impede que elas sejam efetuadas, como enuncia a evocação a seguir, onde Palhaço Zóio diz se aproveitar do corpo já morto para roubar seu chinelo:

Altas cena mesmo nós fazia. [Sempre por causa de acerto?] Ah sempre alguma coisa tinha né cara, nunca era por nada assim né cara, só que esse cara aí morreu de graça, nem tinha sido ele que pegou o revolver, tinha sido o Rafael um cara que morava na casa. [Ele tava lá aquele dia?] Num tava, diz ele que tinha ainda, nem conversei com ele, só que ele disse que tá meio louco da cabeça, esse bagulho aí acho que é mentira, dai o maluco pegou assim, falou que ele tinha ido levar a namorada dele na casa da namorada dele, um ex-marido da namorada dele, desse menino aí surrou ele tá ligado, daí outro dia ele foi com o revolver lá né tá ligado. Daí nós cheguêmo no barraco o revolver não estava no barraco, tava com o Rafael, só que nós nem sabia né cara, ele não avisou que ia pegar o revorve dai mataram o Paulinho né. Eu aquele dia eu só peguei o chinelo do Paulinho, chinelo da mormai massa, daí taquêmo um fogo no barraco, até hoje tem lá os bagulho tá lá ainda, nem vi, nem mudou nada, ninguém entra no barraco, tudo queimado lá (Palhaço Zóio).

As ações entre amigos são caracterizadas não só pela continuidade aos processos de subjetivação, na relação de si com o outro, mas, pelas performances de masculinidade, esses jovens do sexo masculino são convidados a dar uma continuidade exacerbada, pela via da coragem e violência, como está expresso nas experiências da 'morte como autor' presentes na espacialidade do 'mocó':

Nessa ele já puxou uma faca, ele foi pra me dar uma facada, daí o Maringá pegou o revorve deu um tiro na testa dele assim cara e ele saiu correndo batendo a cabeça assim cara, fiquei de cara, o maluco saiu correndo chacoalhando a cabeça e esse Ramirez entrou pra dentro do barraco assim, tento pular a janela, dei altos tiro nas costa nele assim, ele caiu assim, daí peguemo o Ramirez assim pelas perna e jogâmo lá no esgoto lá. [Daí não morreu?] Morreu, morreu, acho que morreu, diz os cara que morreu, eu nunca mais vi o cara né, nunca mais vortemo né cara, taquêmo fogo na casa e saímo vazado. Daí peguemo, nós só encostava nele ele só ficava assim cara, só vibrando assim e o outro maluco que levou um tiro na testa foi subindo assim no barranco daí os cara foram atrás dele assim porque né mano, tirou assim, depois fui ver os zóio dele tava sartado pra fora, esse morreu mesmo eu vi. E esse Ramirez lá nós joguemo ele no esgoto, nós pá, saímo vazado, daí taquemo fogo assim nada casa, moçado o barraco lá. [Lá no Maracanã?] Lá no Maracanã, na beira do Santo Antônio. Os cara andavam comigo, mataram mais uns sete cara lá ainda. [Tudo por droga?] Tudo por droga e os cara mataram um velho lá, porque o véio queria caguetá o barraco. Tinha um monte de coisa, altas cena (Palhaço Zóio).

O 'mocó' é a espacialidade onde as práticas de morte estão bem presentes e agenciadas às performances de masculinidade, intersecionadas com a figura do 'camarada'. Por meio delas provam, ou melhor, desafiam os jovens do sexo masculino além de próximos, ou cúmplices 
da 'morte do outro', tornarem-se também autores de assassinatos.

A espacialidade do 'tráfico' compõe-se através das práticas econômicas do tráfico de drogas, constituindo inter-relações com as vilas periféricas da cidade e estabelecendo como ponto de distribuição, uso e venda da droga as bocas, ou mocós. As práticas econômicas são agenciadas em práticas informais de cobrança, ameaças e por vezes, morte. Contudo, a territorialidade do tráfico de drogas se espraia nas micro-relações de poder da 'vila' e oferece para as formas de subjetividades locais a possibilidade de um engajamento financeiro expressos nas evocações de 'futuro'. Aliás, o 'tráfico' é a espacialidade da relação paradoxal entre a possibilidade de 'futuro' no sentido econômico e a presença iminente da morte.

A 'morte' concentra $10 \%$ das suas evocações no 'tráfico', dividindo-se em dois eixos, primeiramente a 'morte de si' $(80 \%)$ e a 'morte como autor' (20\%). Portanto, a centralidade das evocações sobre a 'morte de si' reflete os dispositivos de cobrança do tráfico, enunciando sempre as ameaças de morte. Os jovens do sexo masculino, divididos entre usar e vender a droga, precisam sempre administrar suas atividades simultaneamente a administrar a própria vida, como mostra a fala de Severino Loco:

Tipo assim eu nunca fiquei devendo pra ninguém cara, eu sabia, primeira coisa que o patrão meu falou é: oh, nunca fique devendo pra ninguém, se ficar devendo pra alguém o cara vai te matar, se não matar você, matam tua família, aí eu fui aprendendo, nunca fiquei devendo pra ninguém, pegava uma ali e já pagava na hora (Severino Espiado).

A vida acontece em ato, através de formasde-vida que não se dissociam das práticas cotidianas, que através de práticas políticas de governo de si, os sujeitos permanecem vivos até aqui. $\mathrm{O}$ cotidiano de jovens que participam da espacialidade da droga, ou seja, uso e tráfico está repleto de governos imediatos da vida, divididos entre evitar morrer, fazendo os 'corres' para quitar as dívidas e deixar a morte em segundo plano diante da vida instantânea do uso de drogas. Portanto, é preciso uma boa administração das práticas de uso e tráfico de drogas para não ser morto.

O 'tráfico' também estabelece agenciamentos com uma possibilidade de 'futuro' e amizade com o 'camarada', concomitante a isso é também espaço de morte como ameaça e medo cotidiano. Como exemplificam as falas de Ribeiro Loco e Bola Magrão:

[E se ficasse devendo muito assim, como que era?] Ah cara, igual esse cara que puxou a arma pra mim, uma vez nossa, ele ficou devendo. Ah não, essa foi uma vez que ele trouxe a polícia lá e os caras quase mataram ele de tanta bordoada tá ligado. Não, mas, os cara ficavam devendo assim e os caras chegavam e iam atrás do cara, tipo se desse pra matar eles matavam tá ligado, bem sinistro (Ribeiro Loco).

[E nessas cobranças que os caras faziam, você teve medo de morrer alguma vez assim?] Ah a gente sempre tem né. [Teve alguma situação que você quase morreu?] Só levava coronhada. [Coisa pior assim não?] Ah os cara vem com revólver, davam coronhada na gente (Bola Magrão).

Ao mesmo tempo a morte é 'amenizada', ou ao menos, torna-se mais silenciosa e menos ameaçadora, quando os meninos fazem uso de drogas. Sempre que perguntados sobre o medo de morrer, ou de frequentar algum lugar específico da cidade, a maioria não negava o medo, porém, diziam eles que, quando presente numa 'cena louca' 
ou mergulhado no uso excessivo da droga, a morte passava a ser uma companhia taciturna. Como conta Bola Magrão, que mesmo afirmando medo, diz ter precisado da intervenção da mãe:

Daí eu comecei a trabalhar, se não o piazão ia me matar tá ligado. [Chegou a te ameaçar?] Chegou a me ameaçar, falou que ia me matar, daí eu comecei a trabalhar. Trabalhava e todo dinheiro que eu pegava comecei a fumar também, daí teve um dia que a minha mãe falou com o carinha lá que trabalhava, tá ligado, daí ele não me deu o dinheiro, não me deu o dinheiro daí eu abandonei o serviço, mas daí minha mãe pegou o dinheiro, ela foi lá e pagou o piazão. Eu recebia $R \$ 600,00$, daí ela foi lá e deu seiscentão pro piá (Bola Magrão).

Os dispositivos econômicos do tráfico de drogas dão continuidade às formas de subjetividade violenta presente na espacialidade do 'tráfico', essa continuidade se faz pelo poder estratégico e disciplinar e 'se querer sair pra querer mudar de vida os cara te matam', palavras de Palhaço Zóio.

$\mathrm{O}$ agenciamento dos jovens do sexo masculino com as práticas do tráfico de drogas, se faz então pelo 'futuro', pelas amizades e pela presença da 'morte', às vezes despercebida, conforme as práticas de uso de drogas ou performances de masculinidade.

Também se tem a presença da morte como autor, afinal para uma 'boa' administração da economia a qual os jovens estão vinculados, é necessário ser homem corajoso, como demonstra a fala de Severino Espiado:

Matei um caminhoneiro com dois tiros assim na garganta. [Porque você matou?] Por causa que tipo eu peguei o dinheiro e ele veio atrás chorando: $\hat{o}$ cara me dá não sei o quê, me devolva eu tenho família. [Por causa de droga?] Só que nessa tava eu e mais um amigo e o cara deu outro tiro também (Severino Espiado).

O 'tráfico' é a espacialidade da linearidade entre as práticas econômicas e violentas, coexistindo a possibilidade de um 'futuro' diante da instantaneidade do cotidiano dos meninos e a 'morte' como risco e medo, ao mesmo tempo em que se torna despercebida.

A morte violenta se distribui dentre essas espacialidades erigidas neste artigo: a 'rua', a 'vila', o 'mocó' e o 'tráfico', estando interrelacionada entre elas e tomando as singularidades de cada diagrama. Os agenciamentos concretos embora sejam precários - e precisam ser reafirmados como tal, são 'eficazes' em dar continuidade a própria dinâmica de práticas espaciais desses sujeitos violentos. Elementos pré-discursivos: performances de masculinidade e aspectos estéticos da violência antecipam e posicionam corpos transgressores simultaneamente às práticas de violência nas vila periférica do espaço urbano, nesse caso de Ponta Grossa-PR. O quadro a seguir sintetiza em quais espacialidades estão concentradas as faces da morte:

Diagrama de relações interespaciais e a morte.

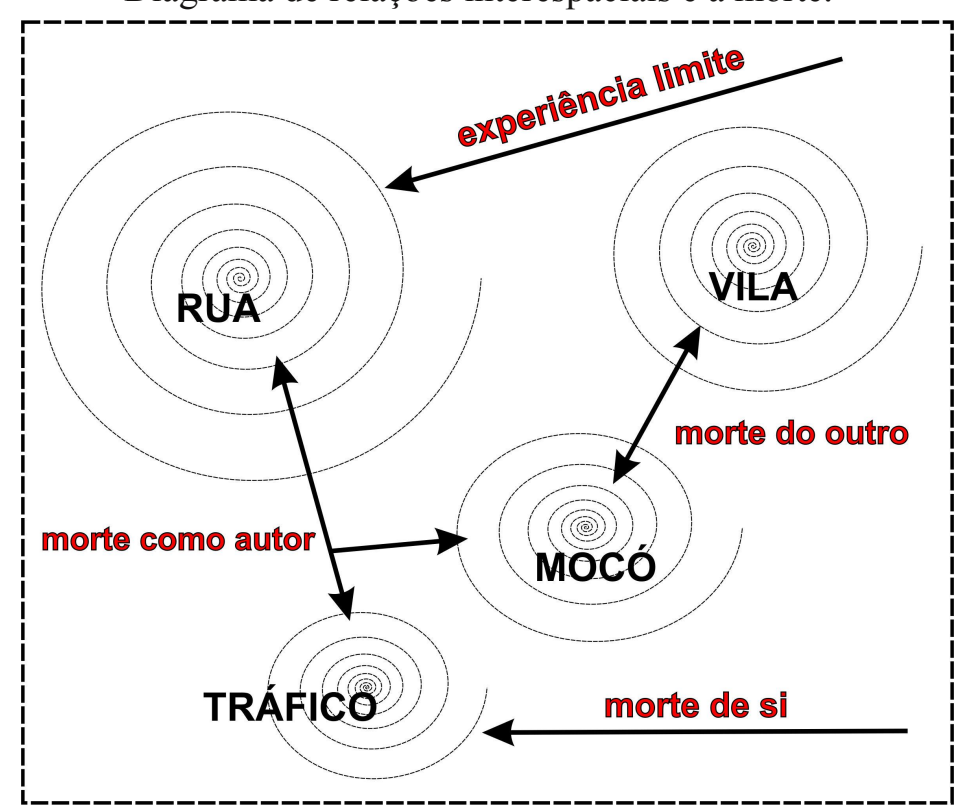

Elaborado por Gomes (2013).

Fernando Bertani Gomes 
Os diagramas aqui construídos são baseados nas categorias discursivas a respeito das vivências espaciais dos jovens do sexo masculino, moradores de vilas pobres e envolvidos com as drogas. Mas, diferente de mapear os lugares e as ações nos lugares, os diagramas foram organizados de maneira a dar inteligibilidade à atualização dos acontecimentos dessas espacialidades, considerando a natureza aberta e sempre em construção do espaço.

A 'rua' é o espaço das eventualidades das 'cenas loucas' e dos 'corres', por meio das quais os meninos estabelecem experiências de quase morte. A 'vila' compõe-se na sua relação com os grupos identitários, pelos 'parceiros', mas também é o lugar do tráfico de droga e das experiências de morte dos outros. O 'mocó é o enunciado da territorialidade do tráfico na 'vila' e nele está presente a figura do 'camarada' com quem os meninos partilham as 'cenas loucas', o uso de drogas e veem outros morrerem como também matam. E o 'tráfico' expressa a linearidade entre o futuro e a morte e seu risco presente.

Através desses componentes gerais, os meninos como formas de subjetividade, performam suas masculinidades agenciados às múltiplas trajetórias e estórias, até agora, de cada espacialidade vivenciada. É por meio dessas linhas de força e estratos do saber que os jovens simplesmente se tornam 'viáveis', os qualificando um corpo posicionado nas relações de poder e inteligível nos domínios do saber.

Portanto, retorna-se a noção de 'profundidade espacial', desconstruindo a própria ideia de profundidade. A relação das formas de subjetividade estudadas aqui, com as práticas de assassinato ou sua proximidade de morrer vítima de homicídio, acontece muito mais pela via dos agenciamentos espaciais que pela representação de um sujeito-substância 'propenso' a violência.
A espacialidade, como diz Massey (2008), compõe-se numa 'constelação de trajetórias' e Rose (1999) diz que o espaço é composto por desejo, de ser frente ao outro, por fantasia, mise-en-scène do desejo e por corporalidade. Tomado isso, pode-se tomar as constelações não só em sua expressão de multiplicidade, mas em seu brilho. Quero dizer que uma constelação pode ser entendida como um conjunto de adornos brilhantes que através da performatividade os sujeitos às transformam em penduricalhos para brilhar e enfeitar-se, ou simplesmente tornar-se cúmplice dos domínios estéticos da espacialidade vivida, seja ela a 'rua', a 'vila' ou o 'tráfico' e sejam os brilhos, roubar, usar drogas ou matar.

\section{Considerações Finais}

$\mathrm{O}$ artigo teve como objetivo compreender como a morte se figura como um elemento inter-relacional das espacialidades vivenciadas por jovens do sexo masculino, moradores de vilas periféricas, pobres e com envolvimento com as drogas. A morte dentre outros componentes relacionais de uma espacialidade toma forma sempre agenciada a outros componentes. As experiências que os jovens do sexo masculino têm da morte de outras pessoas, das autorias de assassinatos, das experiências de quase morte e do risco de vida presente cotidianamente, estão relacionadas às redes de amizades que são formadas através de condutas e estratégias das performances de masculinidade agenciadas à territorialidade do tráfico de drogas das ruas e das vilas periféricas vivenciadas por esses jovens severinos.

1 Nomes fictícios foram adotados para proteger a identidade dos entrevistados.

O termo ' 157 ' refere-se ao artigo 157 do Código Penal Brasileiro, referente a roubo. No caso da evocação, ou se trata de um equívoco, pois o artigo

Fernando Bertani Gomes 
referente a homicídio é o 121 do CPB, ou o entrevistado quis dizer que foi indiciado por outro artigo.

3 Distinguem-se as noções de 'topologia' e 'topografia', a primeiro refere-se à 'cartografia' das atualidades do espaço em devir, a segunda mensura a natureza fechada e fixa do espaço, supondo que ele exista. Sobre isso ver Massey (2008) e Deleuze (2008).

\section{Referências}

BARDIN, Laurence. Análise de conteúdo. Tradução de Luís Antero e Augusto Pinheiro. Lisboa: Edições 70, 1977.

DELEUZE, Gilles. Conversações. São Paulo: Ed. 34, 1992.

DELEUZE, Gilles. Foulcault. Buenos Aires: Paidós, 2008.

FOUCAULT, Michel. História da sexualidade I: a vontade de saber. Rio de Janeiro: Graal, 1988.

FONSECA, Márcio Alves da. Entre a vida governada e o governo de si. In: ALBUQUERQUE JUNIOR, Durval Muniz. VEIGA-NETO, Alfredo, SOUZA FILHO, Alípio. (org.). Cartografias de Foucault. Belo Horizonte: Autêntica Editora, 2011. p. 241.

GOMES, Fernando Bertani. 'Cenas Embaçadas': A relação entre as espacialidades vivenciadas por jovens do sexo masculino e a morte por homicídio na cidade de Ponta Grossa - PR. 2013. Dissertação (Mestrado em Gestão do Território) - Universidade Estadual de Ponta Grossa, Ponta Grossa, Paraná.

GOMES. Paulo Cesar da Costa. Espaços Públicos: um modo de ser do espaço, um modo de ser no espaço. In: CASTRO, Iná Elias de; GOMES, Paulo Cesar da Costa;
CORRÊA, Roberto Lobato. (Org) Olhares Geográficos: modos de ver e viver o espaço. Rio de Janeiro: Bertrand Brasil, 2012, p. $19-42$.

MASSEY, Doreen. Pelo espaço: uma nova política da espacialidade. Rio de Janeiro: Bertrand Brasil, 2008.

ROSE, Gillian. Feminism e geography: the limits of geographical knowledge. Cambridge: Polity Press, 1993.

ROSE, Gillian. Gillian. Performing Space. In: MASSEY, Doreen; ALLEN, John; SARRE, Phillip. Human Geography Today. Cambridge: Polity Press, 1999, p. 247 - 259.

WAISELFISZ, Julio Jacob. Mapa da Violência 2011. Os jovens do Brasil. São Paulo: Ministério da Justiça, 2011.

Recebido em 02 de dezembro de 2013. Aceito em 03 de fevereiro de 2014.

Fernando Bertani Gomes 